\title{
А.Й. ЛАБІНСЬКИЙ
}

Львівський національний медичний університет іл. Данила Галицького

\section{Ендотеліальна дисфункція}

\section{при немедикаментозній гірудотерапії}

\section{в посднанні з мануальною та нутриціологічною корекцією у хворих із транзиторними ішемічними церебральними атаками}

Порушення мозкового кровообігу є основною причиною зростання смертності й непрацездатності населення [2]. Одним із найчастіших маркерів інсульту є транзиторне порушення мозкового кровообігу $[2,3]$. Медикаментозне лікування судинних порушень не розв'язує основне питання - зниження росту цієї захворюваності [2, 5]. Згідно зі сучасними уявленнями, одним із провідних патогенетичних чинників гіпертонічної хвороби та судинних захворювань головного мозку вважається порушення функції ендотелію [2, 3].

Ендотелій - це моношар клітин, що покриває внутрішню поверхню судин і порожнин серця, відіграє важливу роль у підтриманні тонусу

(C) Лабінський А.Й., 2016 
та структури судин, локального гомеостазу та проліферації клітин судинної стінки [8]. Він виконує багато функцій: секреторну, бар'єрну, бере участь у фагоцитозі, регулюе транспорт багатьох біологічно активних речовин (чинників росту, вазоактивних сполук, гормонів, анти- і прокоагулянтів), контролює дифузію води, електролітів, продуктів метаболізму [15]. Ендотелій секретує потужні вазоактивні речовини: вазодилятатори (NO, ендотеліальний гіперполяризуючий чинник, простациклін) і вазоконстриктори (ендотелін, вільні радикали недоокиснених жирних кислот, простагландин F2 $\alpha$ і тромбоксан A2) [6]. Патогенез судинних захворювань, імовірно, пов'язаний з порушенням балансу ендотеліальних субстанцій. Головну роль у розвитку ендотеліальної дисфункції відіграє вільнорадикальне окиснення, продукція потужних вазоконстрикторів, а також цитокінів, які пригнічують продукцію NO [10].

Матеріали й методи дослідження. Методи дослідження функції ендотелію периферійних і вінцевих артерій грунтуються на оцінці його здатності продукувати NO у відповідь на фармакологічні (ацетилхолін, метахолін, брадикінін, гістамін) або фізичні (зміна кровообігу) стимули, а також на прямому визначенні вмісту NO й оцінці рівня ймовірних показників ендотеліальної функції (чинник фон Віллебранда, тканинний активатор плазміногену, тромбомодулін) [7]. За патологічних станів для оцінювання ендотеліальної дисфункції використовуються оклюзійна плетизмографія, коронарографія під контролем УЗД, рентгенологічні методи, магнітно-резонансна томографія, дуплексне ультразвукове дослідження (УЗД) периферійних артерій із проведенням проб, визначення рівня ендотеліальних медіаторів у плазмі, оцінка мікроальбумінурії, визначення кількості десквамованих ендотеліоцитів у крові, визначення NO у видихуваному повітрі.

Найзручнішим і найпоширенішим методом оцінювання стану функціональної здатності ендотелію є дуплексна УЗД периферійних артерій з оцінюванням діаметра плечової артерії до і після ішемії кінцівки. Порушення потокозалежної дилятації плечової артерії є чинником ризику цереброваскулярних захворювань. Для вимірювання діаметра судини зазвичай використовують лінійні датчики 7-8 МГц. Вони зазвичай мають доплерівську функцію, зображення оцінюється в одно- і двовимірному ракурсі. Стимулом залежної від ендотелію дилятації периферійних артерій є реактивна гіперемія. Суть проби полягає в тому, що та чи інша судина підлягає тимчасовому стисненню (наприклад, накладання джгута на плечову ділянку під час ультразвукової доплерографії), після чого оцінюють реакцію судини у відповідь на усунення оклюзії. У нормі має відбуватися розширення артерії та збільшення у ній швидкості кровообігу до 10 \% [11]. В основі подібної реакції лежить накопичення за час оклюзії тканинних метаболітів (головним чином аденозину - потужного вазодилятатора тканинного походження) і безпосередній тоногенний вплив кровоплину або, точніше, напруги-зсуву (потокозалежна дилятація). Метод визначення спричиненої потоком ендотелійзалежної вазодилятації із застосуванням ультразвуку розробили D. Celermajer зі співавторами (1992). Умовно прийнято вважати нормальною реакцією плечової артерії її дилятацію на тлі реактивної гіперемії більш ніж на 10 \% вихідного діаметра; менше іiї значення або вазоконстрикція вважаються патологічними $[10,11,13]$.

Беручи до уваги доступність, неінвазивність та інформативність цього методу, обстежено і проліковано 129 хворих із транзиторними ішемічними атаками. Всі хворі отримували по п'ять сеансів гірудотерапії за розробленими й опублікованими раніше схемами [5]. За декілька днів до початку сеансів гірудотерапії хворих переводили на інший, інноваційний спосіб харчування. Зокрема, вилучали з раціону 
трансгенні жири, окрім риб'ячого, екстрактивні речовини у вигляді бульйонів і відварів, солодкі кондитерські вироби. До раціону додавали суміші квіткового пилку, меленого насіння льону і розторопші та меду (по десертній ложці двічі на день перед сніданком і обідом). Застосовано інноваційний режим харчування за біоритмами (патент № 99347 від 25.05.2015), головне правило якого - вживання їжі тільки за настання стійкого почуття голоду, відповідно до чого зсувався режим прийому їжі. Достатню кількість антиоксидантних і баластних речовин забезпечували підвищеним вмістом (до 2 кг) у раціоні фруктів і соків фреш. Для поліпшення мозкового кровообігу у вертебробазилярному басейні застосовували мануальну терапію у вигляді пневмовакуумного масажу з постізометричною релаксацією та мобілізацією шийно-грудного відділу хребта. Як відомо, остеохондроз у шийно-грудному відділі хребта порушуе кровопостачання головного мозку. У хворих до лікування спостерігалися періодичні короткочасні запаморочення та інші симптоми, характерні для цієї патології. Артеріальний тиск у всіх пацієнтів був підвищений (від 140 на 90 до 175 на 105 мм рт. ст.).

Результати дослідження та їх обговорення. Після лікування у всіх хворих знизився артеріальний тиск, у більшості з них зникли періодичні напади запаморочення та інші прояви.

Кількість пацієнтів із транзиторними ішемічними атаками до і після лікування та осіб контрольної групи з різним ступенем потокозалежної вазодилятації

\begin{tabular}{|c|c|c|c|}
\hline $\begin{array}{c}\text { Ступінь } \\
\text { вазодилятації }\end{array}$ & $\begin{array}{c}\text { Контрольна } \\
\text { група, осіб }\end{array}$ & $\begin{array}{c}\text { Група } \\
\text { до лікування, осіб }\end{array}$ & $\begin{array}{c}\text { Група } \\
\text { після лікування, осіб }\end{array}$ \\
\hline $\begin{array}{c}\text { Відсутність } \\
\text { вазодилятації, } \\
\text { незначна } \\
\text { вазоконстрикція }\end{array}$ & - & $4(3 \%)$ & - \\
\hline $\begin{array}{c}\text { Вазодилятація } \\
\text { 0-3\% }\end{array}$ & - & $60(47 \%)$ & $25(19 \%)$ \\
\hline $\begin{array}{c}\text { Вазодилятація } \\
3-6 \%\end{array}$ & 12 & $44(34 \%)$ & $42(33 \%)$ \\
\hline $\begin{array}{c}\text { Вазодилятація } \\
6-9 \%\end{array}$ & 28 & $21(16 \%)$ & $62(48 \%)$ \\
\hline
\end{tabular}

За результатами дослідження ступеня вазодилятації виокремлено такі групи: 1) пацієнти (4 особи), у яких не було вазодилятації, натомість спостерігалася незначна вазоконстрикція $0-3 \%$ i найбільш виражена симптоматика захворювання; 2) пацієнти (60 осіб), у яких вазодилятація була дуже незначною (0-3 \%) порівняно 3 контрольною групою людей; 3) пацієнти (44 особи), у яких ступінь вазоконстрикції становив $3-6 \%$; 4) пацієнти (21 особа), у яких ступінь вазоконстрикції наближався до нормального (6-9\%), а симптоматика захворювання була найменш вираженою. Як бачимо з таблиці та рис. 1 , 2 , після лікування спостерігалась повна відсутність пацієнтів, у яких до лікування був дуже незначний ступінь вазодилятації (до 3 \%) та парадоксальна вазоконстрикція. Кількість пацієнтів, у яких вазодилятація наближалась до нормальної, виросла більш ніж удвічі, що, за теоремою абсолютної більшості, доводить без додаткових статистичних обчислень високу достовірність такої зміни. 


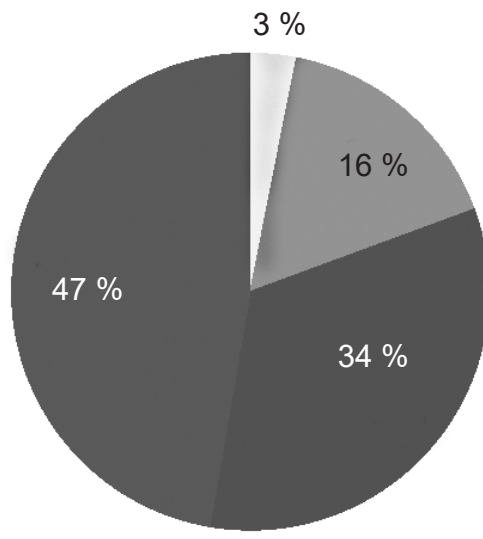

вазоконстрикція до 3 \%

вазодилятація 6-9 \%

вазодилятація 3-6 \%

вазодилятація 0-3 \%

Рис. 1. Ступінь вазодилятації в групах пацієнтів до лікування.

Порівняно 3 контрольною групою (рис. 3) кількість пацієнтів після лікування, у яких ступінь вазодилятації став такий, як у більшості контрольної групи, становила $48 \%$. Кількість пацієнтів, у яких ступінь вазодилятації був надзвичайно низький (0-3 \%), зменшилась до $19 \%$ (25 осіб). Клінічні прояви захворювання в цій групі пацієнтів також регресували пропорційно до нормалізації ендотеліальної функції, вираженої в зростанні ступеня вазодилятації.

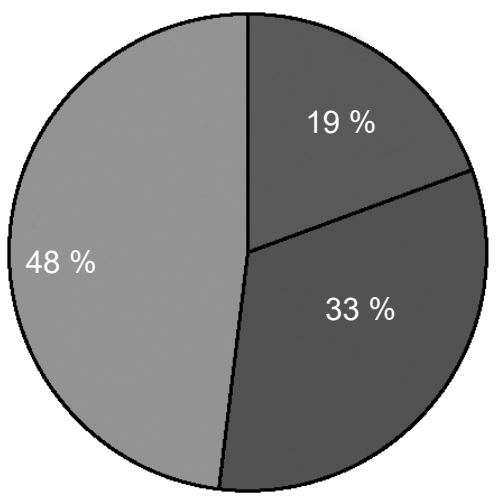

口 вазодилятація до 0-3 \%

口 вазодилятація 3-6 \%

口 вазодилятація 6-9 \%

Рис. 2. Ступінь вазодилятації в групах пацієнтів після лікування.

Слід зазначити, що навіть у контрольній групі ступінь вазодилятації не у всіх був максимально нормальним, тобто близько $10 \%$. Майже у третини ступінь вазодилятації становив близько $6 \%$. Отже, можна вважати, що у 81 \% нормалізувалась функція ендотелію.

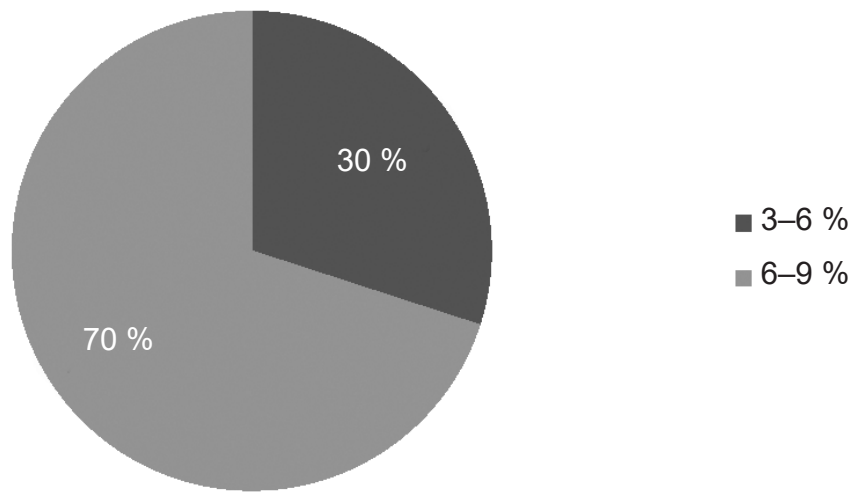

Рис. 3. Ступінь вазодилятації в контрольній групі. 
Позаяк функція ендотелію периферійних і церебральних артерій, яка грунтується на його здатності продукувати NO, прямо пропорційна ступеню вазодилятації у відповідь на зміну кровообігу, може йтися про відновлення регуляції транспорту багатьох біологічно активних речовин (чинників росту, вазоактивних сполук, гормонів, анти- i прокоагулянтів) при застосованому нами лікуванні. Розмірковуючи, яким чином гірудотерапія і нутриціологічна корекція може вплинути на ендотелій судин, слід зазначити здатність гірудину блокувати внутрішньосудинний механізм згортання крові та поляризацію мембран ендотелію і тим самим посилити його секрецію. Речовини антиокиснювального захисту (біофлавоноїди ремнацетин і кверцетин), що в значній кількості містилися в раціоні пацієнтів, знизили процеси пероксидного окиснення ліпідів, як одного з головних патохімічних механізмів ендотеліальної дисфункції $[3,5,6]$. Такий вплив гірудину і застосованої нутриціологічної корекції посилювався відновленням кровопостачання у вертебробазилярному басейні головного мозку завдяки мануальній терапії, яка усуває елементи остеохондрозу шийного відділу хребта й екстравазальної компресії хребтових артерій.

Висновки. Інноваційне комплексне лікування із застосуванням гірудотерапії з мануальною та нутриціологічною корекцією при транзиторних ішемічних атаках поліпшує об'єктивно стан хворих і ступінь вазодилятації при УЗД артерій, що свідчить про відновлення їх ендотеліальної функції. Гірудотерапія з мануальною та нутриціологічною корекцією є ефективним комплексним інноваційним лікуванням та рекомендується застосовувати при транзиторних ішемічних атаках.

\section{СПИСОК ЛІТЕРАТУРИ}

1. Алосова E.H. Метаболическая терапия повреждения миокарда, обусловленного ишемией : новый подход к лечению ишемической болезни сердца и сердечной недостаточности // Український кардіологічний журнал. - 2000. - № 3. - С. 85-92 (Amosova E. Metabolic therapy of damage of themyocardium conditioned by an ischemia: new going neartreatment of ischemic heart and heart failure // Укр. кардіол. журн. 2000. - N 3. - С. 85-92). 2. Волошин П.В. Аналіз поширеності та захворюваності на нервові хвороби в Україні / П.В. Волошин, Т.С. Міщенко, Є.В. Лекомцева // Международный неврологический журнал. - 2006. - № 3. - С. 9-13 (Voloshyn P. Analysis of prevalence and morbidity onnervous illnesses in Ukraine / P. Voloshyn, T. Mishchenko, V. Lekomseva // International neurological magazine. - 2006. - N 3. - C. 9-13). 3. Досенко B.C. Патофізіологічні аспекти генетичного поліморфізму ендотеліальної NO-синтетази / В.Є. Досенко, В.Ю. Загорій, О.О. Мойбенко, О.М. Пархоменко // Фізіологічний журнал. - 2002. - Т. 48. - № 6. - C. 86-102 (Dosenko V. Physiopathology aspects of genetic polymorphism of endothelial NO-sintetaza / V. Dosenko, V. Zahorij, O. Mojbenko, O. Parhomenko // Phisiolic magazine. - 2002. - Vol. 48, - N 6. - P. 86$102)$ ). 4. Делко А.П. Клинические аспекты фармакологической коррекции коронарной и сердечной недостаточности, эндотелиальной дисункции у больных инфарктом миокарда, ассоциированным с артериальной гипертонией / А.П. Демко, Н.И. Тарасов, А.Т. Тепляков // Кардиоваскулярная терапия и профилактика. -2003 . - № 6. - С. 18-26 (Demko A. Clinical aspects of pharmacological correction of coronal and cardiac insufficiency, endothelial дисункиии for patients by the heart attack of myocardium, associated with arterial high blood pressure / A. Demko, N. Tarasov, A. Tepljkov. Kardiovaskyljr. therapy and prophylaxis. - 2003. - N 6. - P. 18-26). 5. Лабінський А.Й. Немедикаментозне лікування транзиторних ішемічних атак і профілактика мозкових інсультів із біохімічним дослідженням ліпідного гомеостазу волосяних фолікул та волосся пацієнтів (поєднання гірудо-, мануальної терапії та нутриціологічної корекції) / А.Й. Лабінський // Український вісник психоневрології. - 2015. - Т. 23, вип. 4 (85). - С. 17-21 (Labinskyy A. Unmedicamental treatment of ischemic attacks and prophylaxis of cerebral strokes with biochemical research of lipid homoeostasis of hair follicle and hair of patients (of combination of girudo, manualnoi therapy and nutriciologichnoi correction / A. Labinskyy // Ukrainian announcer of psychoneurology. - 2015. - Vol. 23, suppl. 4 (85). - P. 17-21). 6. Максютина Н.П. Використання нових лікарських форм кверцетину при ішемічних та радіаційних ушкодженнях: метод. рекомендації / Н.П. Максютина, О.О. Мойбенко, О.М. Пархоменко [та ін.]. - К., 2000. - 13 с. (Maxutina $N$. Using of new medical forms of Quercetinum for ischemic and radiation damages / N. Maxutina, O. Moibenko, O. Parchomenko [et al.] // Method. recommendations. - K., 
2000. - 13 р.). 7. Мойбенко О.О. Дослідження ролі ендотелійзалежних факторів у реалізації кардіогенних рефлексів за нормальних і патологічних умов / О.О. Мойбенко, В.Б. Павлюченко, В.В. Даценко [та ін.] // Фізіологічний журнал. - 2000. - Т. 46. № 2. - C. 19-32 (Moibenko O. Research of role of endothelia of dependent factors is in realization of cardiogenic reflexes at the normal and pathological terms / O. Moibenko, V. Pavljtsenko, V. Dacenco [et al.] // Phisiolic. magazine. - 2000. - Vol. 46. - N 2. P. 19-32). 8. Олиельяненко М.Г. Клиническое значение эндотелиальной дисфункции при остром коронарном синдроме без подъема сегмента ST у лиц в возрасте до 55 лет / М.Г. Омельяненко, Н.А. Суховей, С.Б. Назаров, В.Г. Плеханов // Российский кардиологический журнал. - 2003. - № 4. - С. 23-27 (Omeljanenko M. Clinical value of endothelial disfunction at a sharp coronal syndrome without getting up of segment ST at persons under age 55 / M. Omeljanenko, N. Syhovej, S. Nazarov, V. Plehanov // Russian cardiologic. magazine. - 2003. - N 4. - P. 23-27). 9. Романовская Г.А. Перспективы медикаментозного лечения эндотелиальной дисфункции / Г. Романовская, Е. Акатова, Г. Гороховская [и др.] // Фарматека. - 2005. - № 19 (114). - С. 23-25 (Romanovskaja $H$. Prospects of medicamental treatment of endothelial disfunction / $H$. Romanovskaja, E. Acatova, H. Gorohovskaja [et al.] // Pharmateka. - 2005. - N 19 (114). - P. 23-25). 10. Bachmann $S$. Nitric oxide in the kidney : synthesis, localization, and function. Am. / S. Bachmann, P. Mundel // J. Kidney Dis. - 1994. - Vol. 24. - P. 112-129. 11. Celermajer D.S. Cigarette smoking is associated with dose-related and potentially reversible impairment of endotheliumdependent dilation in healthy young adults / D.S. Celermajer, K.E. Sorensen, D. Georgakopoulos [et al.] // Circulation. - 1993. - Vol. 88 - P. 2149-2155. 12. Celermajer D.S. Non-invasive detection of endothelial dysfunction in children and adults at risk of atherosclerosis / D.S. Celermajer, K.E. Sorensen, V.M. Gooch [et al.] // Lancet. - 1992. - Vol. 340. - P. 1111-1115. 13. Dzau V. The relevance of tissue angiotensin-converting enzyme: manifestations in mechanistic and endpoint data / V. Dzau, K. Bernstein, D. Celermajer [et al.] // J. Cardiol. - 2001. - Vol. 88 (suppl. L). - P. 1-20. 14. Hyndman M.E. The T-786®C mutation in endothelial nitric oxide synthase is associated with hypertension / M.E. Hyndman, H.G. Parsons, S. Verma [et al.] // Hypertension. - 2002. - Vol. 39. - P. 919-925. 15. Napoli C. Nitric oxide and atherosclerosis / C. Napoli, L. Ignarro // Nitric Oxide. - 2001. - Vol. 5 . - P. 88-97. 16. Soloviev A.I. Mechanisms of endothelial dysfunction after ionised irradiation and its prevention by $\alpha$-tocopherol / A.I. Soloviev // J. Physiol. - 2003. - Vol. 3. - P. 24-26.

Стаття надійшла до редколегії 17.02.2016

\title{
Endothelial Dysfunction at Non-medicamental Hirudotherapy in Combination with Manual Therapy and with Nutritsiology Correction for Patients with Transitory Ischemic Cerebral Attacks
}

\author{
A. LABINSKYY \\ Danylo Halytskyi Lviv National Medical University
}

Cerebral vascular diseases continue to remain principal reason of growing death rate and nonoperability of population. One of the most frequent markers of coming stroke is transitory ischemic cerebral attacks. Medicamental therapy of vascular diseases does not solve the basic problem - how to decrease the level of this morbidity. According to modern apprehension, one of the leading nosotropic factors of hypertensive illness and vascular diseases of cerebrum is considered the parafunction of endothelia. Endothelia is monolayer of cages, that covers the internal surface of vessels and cavities of heart, plays an important role to support tone and structure of vessels, local homoeostasis and proliferation of cages of vascular wall. It executes plenty of functions: secretory, barrier, participates in phagocytosis, regulates transportation of many biologically active substances, and controls diffusion of water and electrolytes. Atherosclerosis and endothelial disfunction in the tissues, resulting in disturbances of lipid (cholesterol) and protein metabolism (metabolic arteriosclerosis) in tissues and arteries elastyc and muscle-type elastyc developing specific changes. They reflect the dynamics of the atherosclerotic process, its morphogenesis and are represented by "prelipid changes": lipoidosis, liposklerosis, ateromatosis, and aterocalcynosis. "Prelipid changes" correlate to the processes of increased permeability of cell membranes for metabolic substances (big dispersed proteins, fibrinogen, "inert" cholesterol, its esters, lipoproteyids, mucoproteids, hyaluronidase). As a result, they come from the blood into tunica endothelial. In the article, endothelial disfunction is studied for patients with transitory ischemic attacks at innovative not medicamental treatment by the methods of hirudotherapy combined with manual therapy and nutritsiologic correction. 
Original methodology of research of endothelial disfunction is applied by a simple and informing method of vasodilatation at full-duplex ultrasonic diagnostics of arteries. It is shown that after the conducted innovative treatment the indexes of endothelial disfunction approach normal as in the control group of people on the background normalization of arteriotony and almost complete disappearance of pathological displays. Nutritsiology correction, consisted in setting of free diet with the reception of meal only at the offensive of proof esurience. Transgene fats were withdrawn from the ration and more pectin fibres and antioxidants were added for the improvement of bowel activity. Leeched put on a cervical-neck area for 3-4 on one session one time per week during one and a half months. At the same time, manual therapy was conducted in the type of post-isometric relaxation and mobilization for 2 sessions in a week for avoidance of osteochondrosis and proceeding in blood supply for a backbone. Innovative holiatry with application of hirudotherapy in combination with manual therapy and nutritsiology correction at transitory ischemic attacks the state of patients and degree of vasodilatation improve nutritsiology correction objectively at ultrasonic diagnostics of arteries that testifies to proceeding endothelial function in them. Hirudotherapy with manual therapy and nutritsiology correction proves to be an effective innovative holiatrys and is recommended to apply at transitory ischemic cerebral attacks.

Key words: endothelial disfunction, transitory ischemic attacks, hirudotherapy, nutritsiology correction, manual therapy. 